\title{
Contents, Vol. 33, 1976
}

\section{Index}

No.i

Kohler, K.: Die Instabilität wortfinaler Alveolarplosive im Deutschen: eine elektro-

palatographische Untersuchung

(The Instability of Word-Final Alveolar Plosives in German: an Electropalato-

graphic Investigation)

Fónagy, I.: La mimique buccale. Aspect radiologique de la vive voix

(Radiological Aspects of Emotive Speech)

Malécot, A. and Lindsay, P.: The Neutralization of /ë/-/oë/ in French

Bhatia, T. K.: On the Predictive Role of the Recent Theories of Aspiration

Libri $\quad 75$

No. 2

Plotkin, V. Y.: Systems of Ultimate Phonological Units

Malécot, A.: The Effect of Linguistic and Paralinguistic Variables on the Elision of the French Mute-e 93

Benguerel, A.-P. and Adelman, S.: Perception of Coarticulated Lip Rounding ... 113

Libri 127

No. 3

Lindqvist-Gauffin, J. and Sundberg, J.: Acoustic Properties of the Nasal Tract .... 161 Pétursson, M.: Aspiration et activité glottale. Examen experimental à partir de con-

sonnes islandaises

(Aspiration and Glottal Activity. An Experimental Research Based on Icelandic

Consonants and Consonant Clusters) 169

Hughes, O. M. and Abbs, J. H.: Labial-Mandibular Coordination in the Production

of Speech: Implications for the Operation of Motor Equivalence

199

Koerner, E. F. K.: A Minor Figure in 19th-century French Linguistics: A. Du-

friche-Desgenettes

222

Libri

232

No. 4

Gandour, J. and Maddieson, I.: Measuring Larynx Movement in Standard Thai

Using the Cricothyrometer 241

Priestly, T. M. S.: A Note on the Glottal Stop

268

IV 
Index

Hogan, J. T.: An Analysis of the Temporal Features of Ejective Consonants

275

Mrayati, M. et Carre, R.: Relations entre la forme du conduit vocal et les carac-téristiques acoustiques des voyelles françaises. Etude des distributions spatiales (Relations between the Form of Vocal Tract and the Acoustic Characteristics of

the French Vowels) 285

Richman, M.: The Distribution of /e/-/E/ in French Verb Endings 307

Libri $\quad 320$

No. 5

Pike, E. V. and Oram, J.: Stress and Tone in the Phonology of Diuxi Mixtec

Painter, C.: Pitch Control and Pharynx Width in Twi: An Electromyographic Study 334

Ho, A. T.: The Acustic Variation of Mandarin Tones 353

Vance, T. J.: An Experimental Investigation of Tone and Intonation in Cantonese . 368

Libri 393

Varia 400

No. 6

Broad, D. J.: Toward Defining Acoustic Phonetic Equivalence for Vowels 401

Emerit, E.: Nouvelle contribution à la théorie des locus. 3e partie. L'individualité des formes sonores

(New Contribution to the 'Locus' Theory. 3rd Part. The Individuality of Tone

Shapes)

Libri

425 